\title{
OBITUARY
}

\section{ROBERT KENWORTHY SCHOFIELD}

Soil science suffered an irreplaceable loss by the death on 8 June, 1960, after a short illness, of Dr Robert Kenworthy Schofield, Reader in Soil Science at the University of Oxford.

I) Schofield was born in London in 1901, and was educated at Oundle, and Trinity College, Cambridge, where he obtained a First in Part II of the Natural Sciences Tripos. He will best be remembered for the important contributions which he made to the knowledge of the physical and chemical properties of soils during his 27 ycars at the Rothamsted Experimental Station at Harpenden, most of which he spent in the Physics Department. He succeeded Dr B. A. Keen as head of that department in 1949, and in 1954 was appointed head of the Chemistry Department at Rothamsted. Two years later, in 1956, he transferred to Oxford as Reader in Soil Science.

From his undergraduate days in Cambridge Dr Schofield had displayed an especial interest in surface physics, and at Rothamsted he had the opportunity to develop this interest in his studies of the thermodynamical relations of the soil-water system. One of his bestknown achievements was the introduction of the concept of the $\mathrm{pF}$ of water in soils, but equally important were the many original ideas he contributed to such problems as the nature of the ionic forces in water films and of cation exchange. Some indication of the esteem which was felt for Dr Schofield as an outstanding scientist may be judged from his position as President of the British Society of Soil Science and his selection to be Chairman of Commission I of the International Society of Soil Science.

Those who were privileged to know Dr Schofield were perhaps most impressed by his energetic and ebullient personality, and by the readiness with which he was always prepared to advise on any problem where he felt his knowledge could be usefully applied. He thus developed a wide range of interests outside his own immediate field, and his attention was naturally attracted to the subject of soil mechanics.

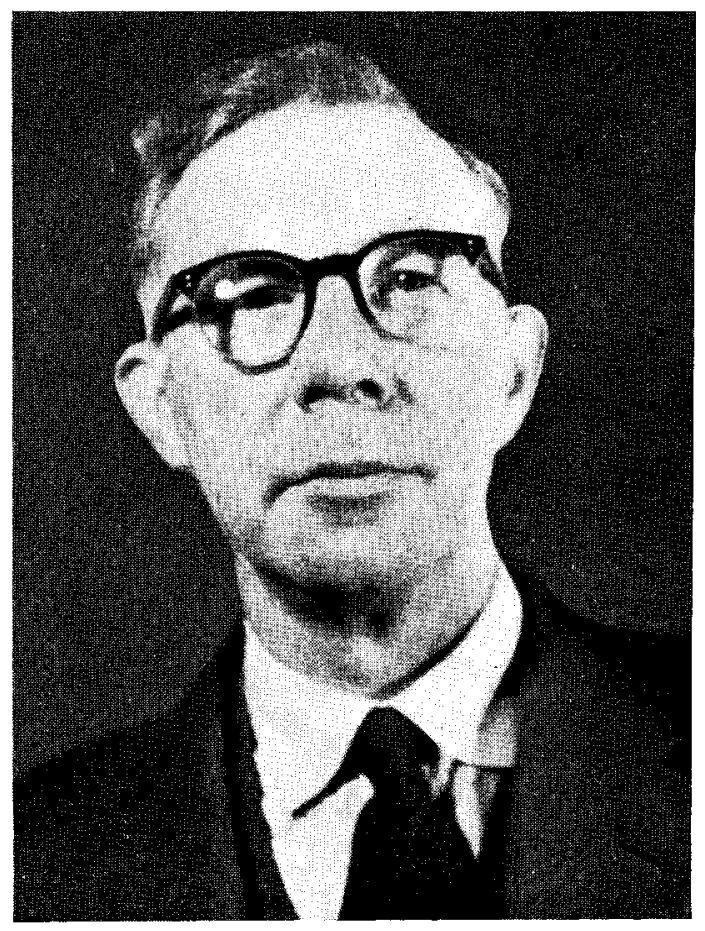
Here he recognized the important applications which his contributions in soil physics had to such soil engineering problems as soil moisture equilibria and shear strength. He gave invaluable advice during the many years which he served on the Road Research Board's Soils Committee, of which he was Chairman at the time of his death.

Those members of the British National Society of Soil Mechanics who were present at the Pore-Pressure Conference held earlier this year will preserve a happy memory of Dr Schofield not only for the way in which his discussions enlivened the proceedings of the Conference, but also for his performance on the whistle and drum, which delighted his audience at the dinner held at Imperial Collegc. 